\title{
PURWARUPA SISTEM IDENTIFIKASI NYAMUK BERDASARKAN CITRA MIKROSKOPIS DIGITAL
}

\author{
Izzati Muhimmah $^{1}$, Novyan Lusiyana ${ }^{2}$, Rizky Eka Listanto ${ }^{1}$, Ratri Agung Nugraheni ${ }^{1}$ \\ Jurusan Teknik Informatika, Fakultas Teknologi Industri, Universitas Islam Indonesia ${ }^{1)}$ \\ Jurusan Pendidikan Dokter, Fakultas Kedokteran, Universitas Islam Indonesia ${ }^{2)}$ \\ Jalan Kaliurang Km. 14,5 Sleman, Yogyakarta 55584 \\ E-Mail:izzati@uii.ac.id ${ }^{1}$,novyan.lusiyana@uii.ac.id ${ }^{2}$, \\ 12523164@students.uii.ac.id ${ }^{3}$,12523156@students.uii.ac.id ${ }^{4}$
}

\begin{abstract}
The modeling of the proposed mosquito identification system is one of the efforts to support the efforts of the Indonesian people in handling zoonotic cases. The incidence of deaths caused by a disease that is naturally transmitted between animals and humans is still quite high. This group of zoonotic diseases include dengue hemorrhagic fever, leptospirosis, cikunguya, and so forth. In the stages of diagnosis, it is necessary to read and identify the type of vector that causes zoonotic disease through microscopic observation. This process is often not done because in this laboratory examination service is not available evenly at the clinic level. In addition, with various types of vectors that the number of variations is very much, needed a way to be able to recognize the vector easily and quickly. Therefore, the prototype of this mosquito identification system needs to be developed. The data used to test system modeling consists of digital microscopic images of mosquito preparations taken from the Parasitology Laboratory of the Faculty of Medicine, Islamic University of Indonesia. Lecturer coordinator of this Parasitology lab will serve as a resource in determining the characteristics of vector and also as a provider of ground truth in the testing phase of the system.
\end{abstract}

Keywords : Identification, Vector Feature, Mosquito, Zoonosis, Microscopic Image.

\section{PENDAHULUAN}

Citra digital adalah citra kontinu yang diubah dalam bentuk diskrit, baik koordinat ruang maupun intensitas cahayanya. Citra digital dapat dinyatakan dalam matriks dua dimensi $f(x, y)$ dimana $\mathrm{x}$ dan y merupakan koordinat piksel dalam matriks (Fahmi, 2007).

\subsection{Image Processing}

Image Processing adalah suatu sistem dimana prosesnya dilakukan dengan masukan citra dan keuaran berupa citra. Tujuan utama dari pengolahan citra adalah untuk mengekstraksi informasi ciri dan perbaikan kualitas citra, dimana hasil dari proses tersebut dapat menampilkan informasi yang jelas.

\subsection{Otsu Tresholding}

Tujuan dari metode otsu adalah membagi histogram citra gray level kedalam dua daerah yang berbeda secara otomatis tanpa membutuhkan bantuan pengguna untuk memasukkan nilai ambang. Pendekatan yang dilakukan adalah analisis diskriminan yang menentukan suatu variabel pembeda agar dapat membagi obyek latar depan (foregraound) dan latar belakang (background) (Putra, 2004).

\subsection{Ekstraksi Fitur}

Ekstraksi fitur merupakan tahap mengambil karakter - karakter penting dalam obyek setelah segmentasi citra dengan menggunakan metode Otsu. Tujuannya adalah untk mengenali suatu obyek dalam citra sehingga dapat dikelompokan berdasarkan ciri yang dimiliki (Ikhsanuddin, 2014).

Pada penelitian ini ada 26 fitur yang akan diekstraksi dari wilayah obyek nyamuk. Fitur ini didapatkan dari beberapa penelitian sebelumnya (Kurniawan, Eling, Sasmito, \& Suryani, 2013). Fitur - fitur tersebut dapat dilihat pada tabel 1 berikut. 
Tabel 1. Fitur Ekstraksi

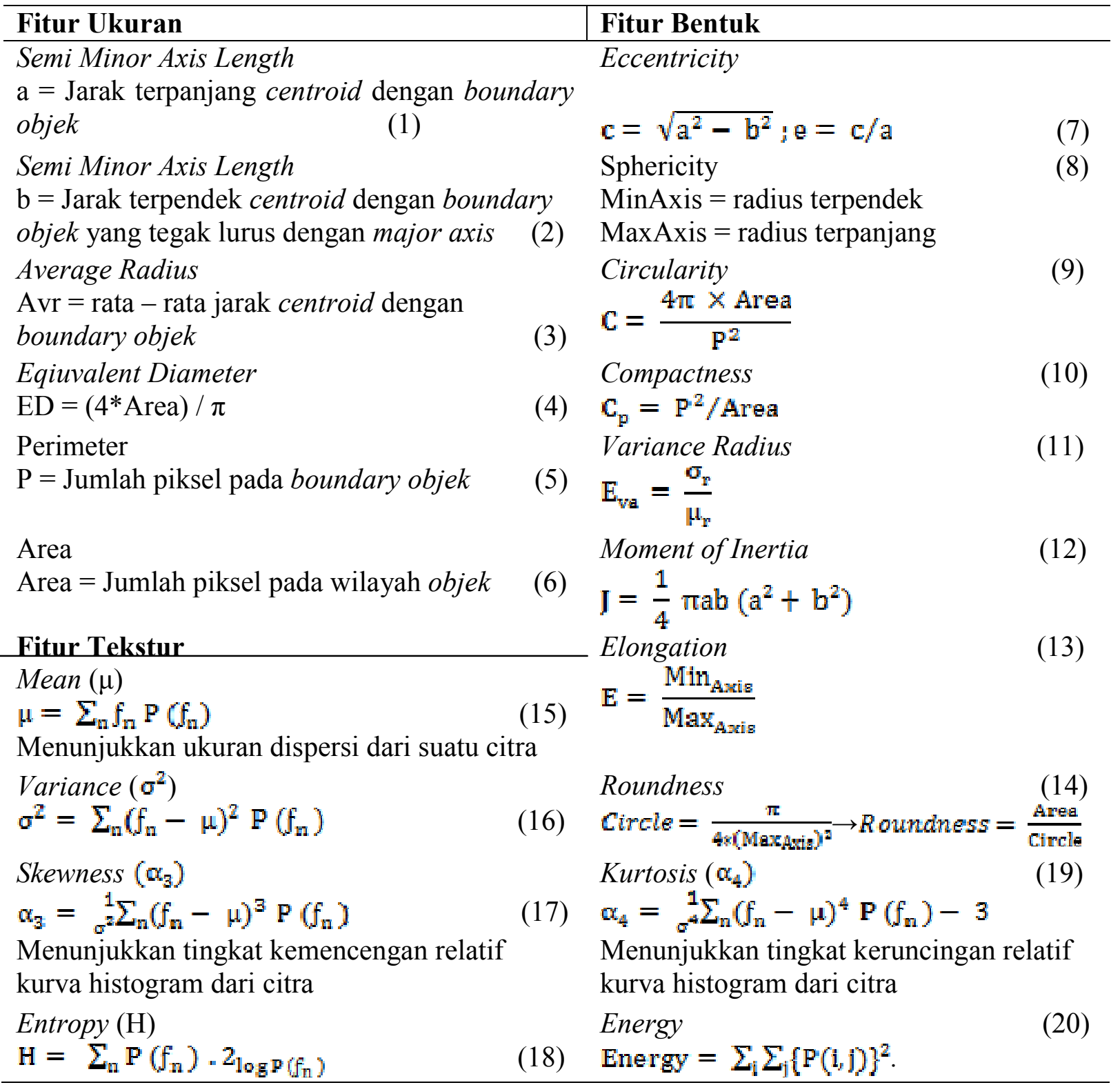

\subsection{Kecedasan Buatan}

Kecerdasan buatan adalah "ide - ide untuk membuat suatu perangkat lunak komputer yang memiliki kecerdasan sehingga dapat melakukan suatu pekerjaan yang dilakukan oleh manusia", dengan kata lain komputer dapat berpikir dan bernalar seperti manusia.
Dengan cara ini, kecerdasan buatan dapat menirukan proses belajar manusia sehingga informasi baru dapat diserap dan digunakan sebagai acuan mendatang dalam menemukan solusi untuk kesimpulan layaknya seorang pakar dalam bidang tertentu (Dhany, 2009). 
Dalam penelitian ini, kecerdasan buatan akan digunakan dalam tahapan klasifikasi yang bertujuan untuk mengelompokan jenis nyamuk berdasarkan fitur yang dimiliki oleh setiap masing-masing jenis.

\subsection{Nyamuk}

Nyamuk termasuk dalam ordo Diptera yang memiliki famili culicidae dan culicini. Genus pada famili ini adalah Aedes Aegypty, Culex sp., Anopheles sp., Mansonia sp. Nyamuk memiliki empat fase perkembangan yaitu telur, lava, pupa dan nyamuk dewasa (Soalani, 2010). Morfologi nyamuk dapat dilihat pada gambar 1 .

Citra digital yang digunakan dalam penelitian ini diambil dari preparat Laboratorium Fakultas Kedokteran UII atas izin dr. Novyan dengan menggunakan kamera mikroskopis dengan perbesaran 4x10 $\mathrm{mm}$. Citra hasil kamera mikroskopis dapat dilihat pada gambar 2 .

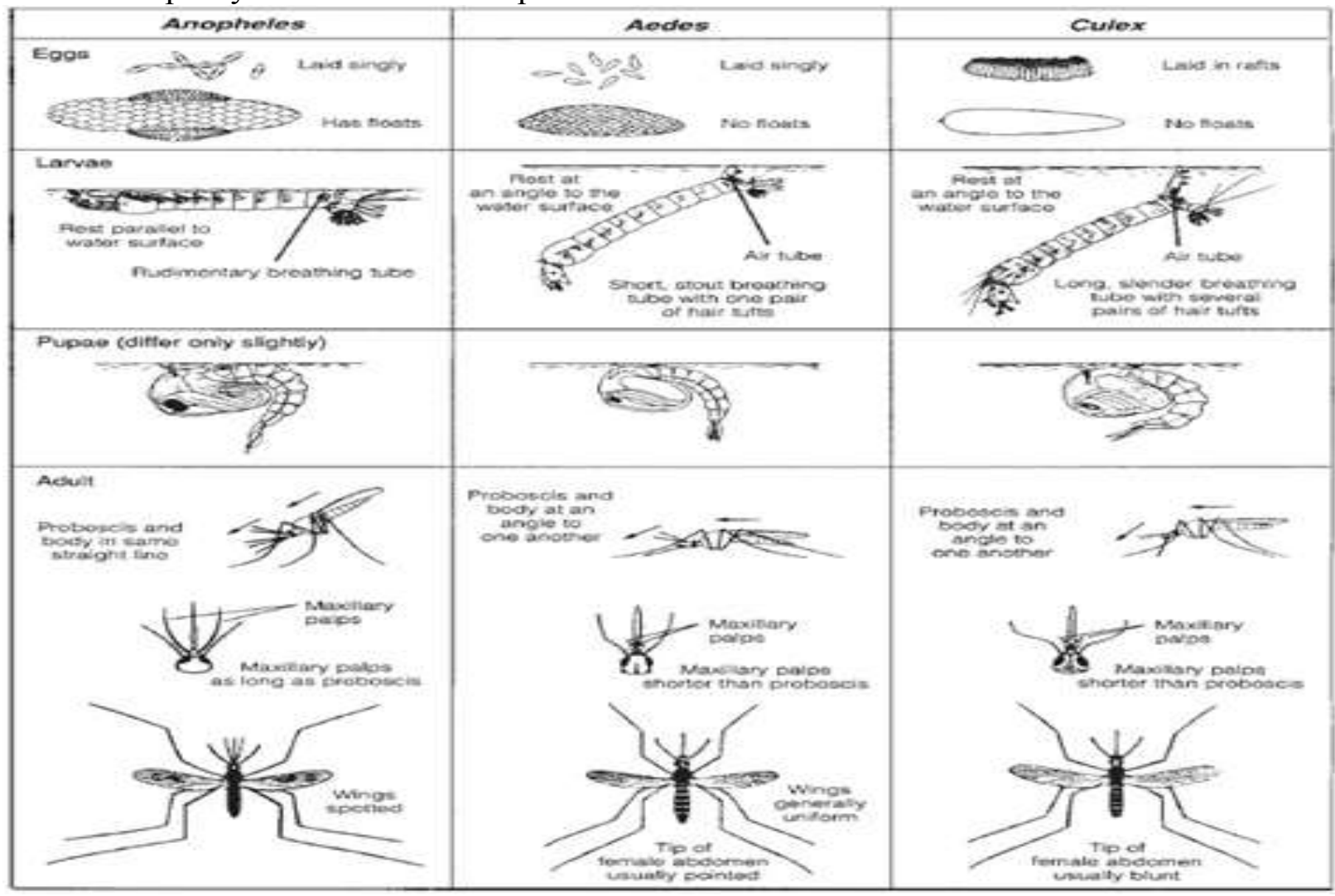

Gambar 1. Morfologi Siklus Nyamuk.

\begin{tabular}{|c|c|c|c|c|c|}
\hline & Telur & Larva & Pupa & Jantan & Betina \\
\hline Aedes & & & & & \\
\hline sp. & & & & & \\
\hline Culex & & & & & \\
\hline sp. & & & & & \\
\hline & & & & & \\
\hline
\end{tabular}

Gambar 2. Citra Digital Nyamuk. 


\section{METODE PENELITIAN}

\subsection{Pengumpulan Data}

Tahapan dalam pengumpulan data pendukung penelitian adalah sebagai berikut

a. Studi literatur untuk menelusuri sumbersumber tulisan yang berisi tentang informasi morfologi nyamuk.

b. Wawancara dengan ahli parasitologi dr. Novyan Lusiyana M.Sc untuk memperoleh informasi rinci tentang perbedaan morfologi dan kebutuhan sistem.

c. Pengumpulan citra digital dari preparat nyamuk yang diambil dengan menggunakan kamera mikroskopis Laboratorium FK Universitas Islam Indonesia. Citra yang diambil menggunakan perbesaran $10 \times 10$ untuk preparat telur dan perbesaran 4x10 untuk preparat nyamuk yang lain. Setiap bagian preparat akan diambil lima sampling citra digital yang nanti kan digunakan sebagai dataset.

\subsection{Usulan Sistematika Proses}

Rancangan awal sistematika proses dalam sistem ini dapat dilihat dari gambar 3 .

\subsection{Perancangan}

\subsubsection{Hasil Perancangan}

Pada hasil perancangan, terdapat beberapa alur diagram sebagai perancangan membuat sistem. Alur diagram tersebut diantaranya :

\section{a. Diagram alur sistem Ekstraksi Ciri}

Setelah citra di masukkan ke dalam sistem, pengguna hanya akan diminta untuk memproses data citra. Citra masukan tersebut kemudian diubah menjadi citra abu abu. Kemudian dilakukan proses segmentasi dan menghasilkan citra baru yaitu citra hasil segmentasi. Kemudian citra segmentasi tersebut akan diproses dan dihitung cirinya dan akan dikeluarkan dalam bentuk tabel.

b. Diagram alur sistem Klasifikasi

Pada sistem klasifikasi, Citra masukan akan diubah menjadi citra abu - abu. Kemudian dilakukan proses segmentasi dan menghasilkan citra baru yaitu citra hasil segmentasi. Kemudian citra segmentasi tersebut akan diproses dan dihitung cirinya dan diklasifikasi sesuai jumlah citra yang diseleksi. Kemudian sistem akan mengeluarkan hasil ekstraksi citra, hasil klasifikasi, dan training set.

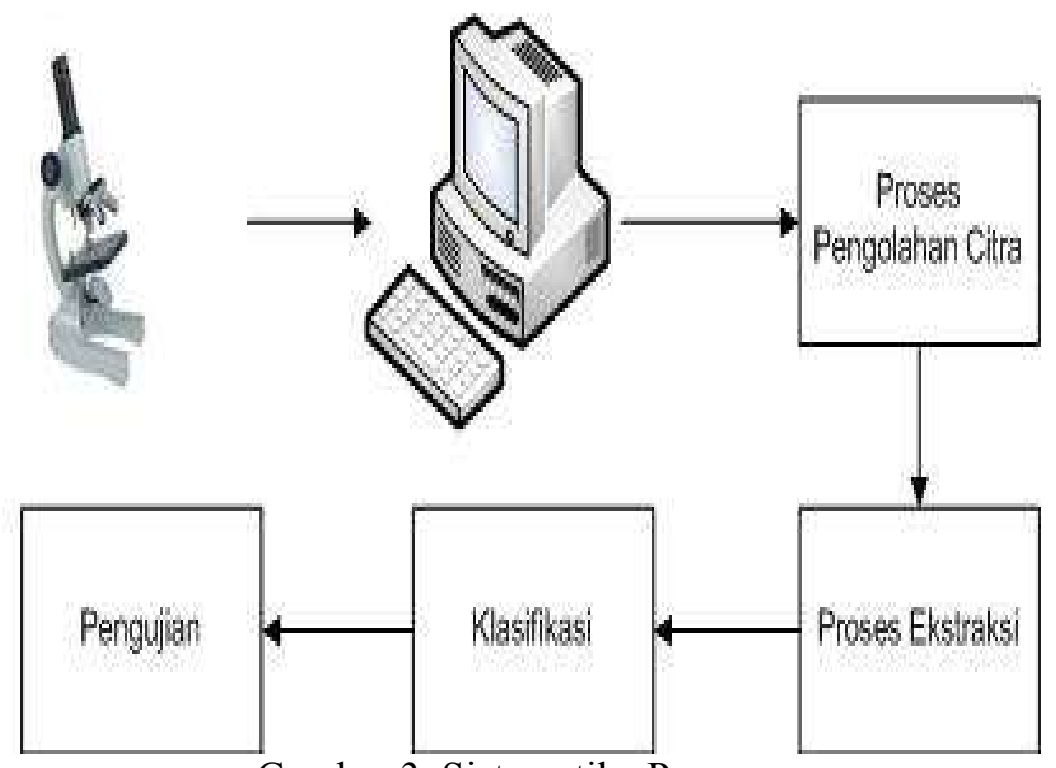

Gambar 3. Sistematika Proses. 


\subsection{Rancangan Pengujian}

\subsubsection{Validasi Ekstraksi Ciri}

Untuk membuat akurasi tinggi dalam klasifikasi, maka dilakukan uji ekstraksi ciri melalui Feature Selection dengan menggunakan CFS (Correlation based Feature Selection). Metode yang digunakan sebagai pembanding tingkat akurasi adalah Best First dan Greedy Stepwise. Tingkat akurasi dihitung dengan menggunakan aplikasi weka.
Dari gambar 6, dapat dilihat bahwa yang fitur yang paling berpengaruh dalam proses klasifikasi untuk menentukan jenis nyamuk adalah yang memiliki presentase tinggi. Seperti maJax (Mayor Axis Length), miJax (Mayor Axis Length), equivD (Equivalent Diameter) dan Circularity dengan presentase $100 \%$. Dari hasil tersebut kita dapat menghapus atribut yang memiliki presentasi 0\% yaitu Elongation dan Min A Sphericity.

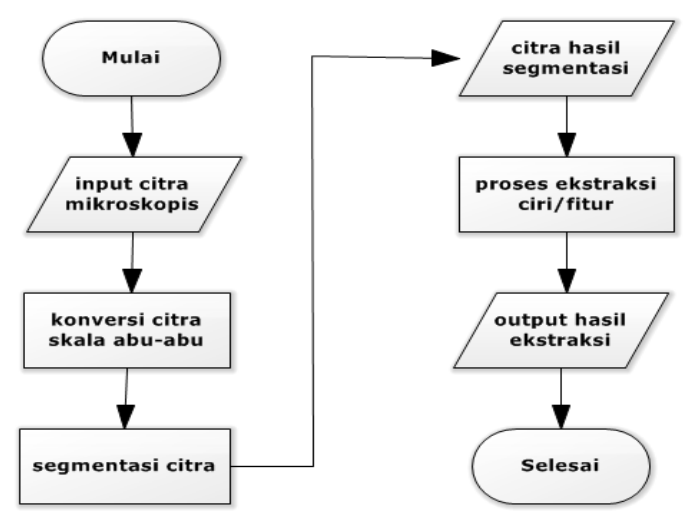

Gambar 4. Diagram Alur Ekstraksi Ciri.

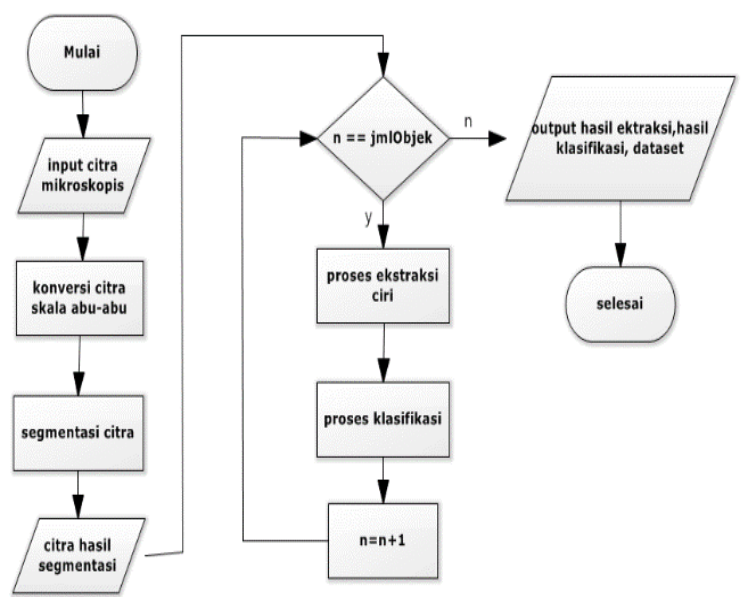

Gambar 5. Diagram Alur Klasifikasi.

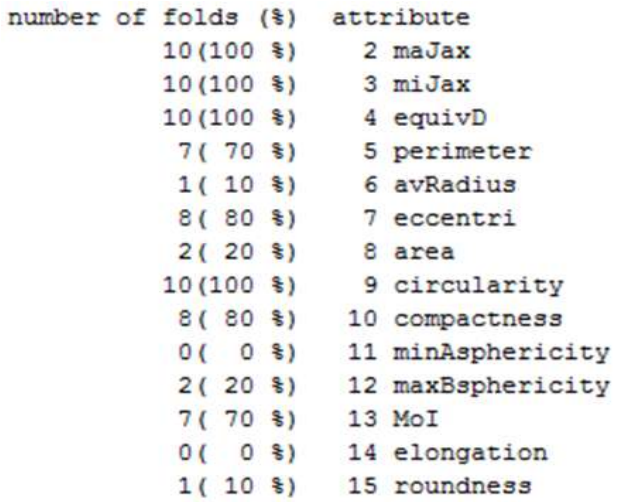

Gambar 6. Contoh Hasil Fitur Seleksi pada Siklus Telur. 
a) Hitungan Ekstraksi Nyamuk Aedes

Tabel 2. Hitungan Ekstraksi Fitur Telur Nyamuk Aedes

\begin{tabular}{cc}
\hline Fitur & Rata - Rata Aedes \\
\hline Semi minor axis length & 455,4826743 \\
Semi minor axis length & 1204,227816 \\
Average radius & 514,8877319 \\
Perimeter & 3235,135032 \\
Eccentricity & 0,918643163 \\
Sphericity & 0,619755133 \\
Circularity & 0,515960707 \\
Compactness & 24,92924 \\
Moment of inertia & 2169036,32 \\
Elongation & 0,38728147 \\
Roundness & $9,51725 \mathrm{E}+11$ \\
\hline
\end{tabular}

Tabel 3. Hitungan Ekstraksi Fitur Larva Aedes

\begin{tabular}{cc}
\hline Fitur & Rata - Rata Aedes \\
\hline Semi minor axis length & 910,1037 \\
Equivalent diameter & 1041,536 \\
Average radius & 0,093381 \\
Contrast & $4,02 \mathrm{E}+12$ \\
\hline
\end{tabular}

Tabel 4. Hitungan Ekstraksi Fitur Pupa

\begin{tabular}{cc}
\hline Fitur & Rata - Rata Pupa \\
\hline Semi minor axis length & 913,8987 \\
Semi minor axis length & 1895,563 \\
Average radius & 2720,422 \\
Perimeter & 17092,92 \\
Compactness & 251,2365 \\
Moment of inertia & 5967445 \\
Contrast & 0,047684 \\
Correlation & 0,928752 \\
Kurtosis & 2,174311 \\
\hline
\end{tabular}

Tabel 5. Hitungan Ekstraksi Fitur Kepala Jantan Nyamuk Aedes

\begin{tabular}{cc}
\hline Fitur & Rata - Rata Aedes \\
\hline Contrast & 0,047684 \\
Correlation & 0,928752 \\
Kurtosis & 2,174311 \\
\hline
\end{tabular}

Tabel 6. Hitungan Ekstraksi Fitur Kepala Betina Nyamuk Aedes

\begin{tabular}{cc}
\hline Fitur & Rata - Rata Aedes \\
\hline Contrast & 0,047684 \\
Correlation & 0,928752 \\
Kurtosis & 2,174311 \\
\hline
\end{tabular}


Tabel 7. Hitungan Ekstraksi Fitur Telur Nyamuk Anopheles

\begin{tabular}{cc}
\hline Fitur & Rata - Rata Anopheles \\
\hline Semi minor axis length & 411,139651 \\
Semi minor axis length & 880,4338137 \\
Average radius & 560,1710587 \\
Perimeter & 3519,658566 \\
Eccentricity & 0,876825192 \\
Sphericity & 0,685163782 \\
Circularity & 0,397670026 \\
Compactness & 52,61013424 \\
Moment of inertia & 1233268,718 \\
Elongation & 0,472424818 \\
Roundness & $2,73834 \mathrm{E}+11$ \\
\hline
\end{tabular}

Tabel 8. Hitungan Ekstraksi Fitur Telur Anopheles

\begin{tabular}{cc}
\hline Fitur & Rata - Rata Anopheles \\
\hline Semi minor axis length & 633,5456571 \\
Equivalent diameter & 844,7365707 \\
Variance radius & 0,045213618 \\
Contrast & 3695259757986,97 \\
\hline
\end{tabular}

Tabel 9. Hitungan Ekstraksi Fitur Kepala Nyamuk Anopheles

\begin{tabular}{cc}
\hline Fitur & Rata - Rata Anopheles \\
\hline Contrast & 0,08722549 \\
Correlation & 0,933740042 \\
Kurtosis & 0,296998609 \\
\hline
\end{tabular}

\subsubsection{Validasi Hasil Klasifikasi}

Untuk mencari tingkat akurasi maksimal dari hasil ekstraksi ciri, hasil dari seleksi fitur akan diuji akurasinya dengan menggunakan aplikasi data mining Weka. Klasifikasi yang digunakan sebagai pembanding untuk mendapatkan akurasi teringgi adalah metode klasifikasi Naive Bayes dan KNN.

\subsubsection{Validasi Sistem}

Uji validitas sistem akan menggunakan metode Single Decision Threshold yang menggunakan suatu threshold untuk menentukan apakah suatu kondisi teridentifikasi salah satu jenis nyamuk.

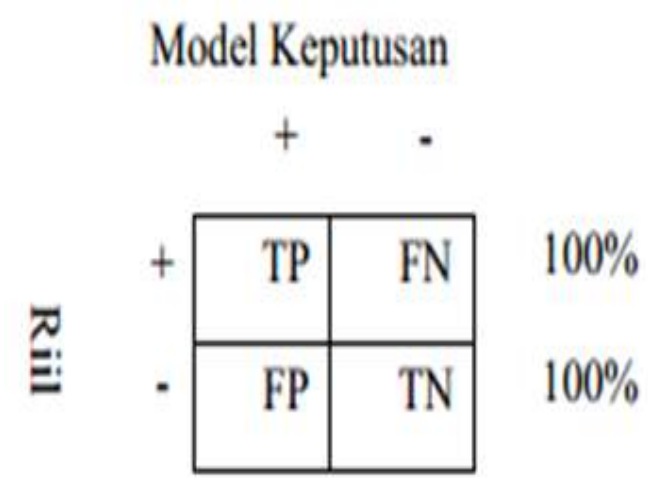

Gambar 7. Single Decision Threshold. 
Terdapat empat parameter diagnosis yang akan ditunjukan dalam prosentase. Rumus untuk mendapatkan nilai prosentase parameter tersebut adalah :

$$
\begin{aligned}
& \% \mathrm{TP}=\frac{T P}{T P+F N} x 100 \% \\
& \% \mathrm{FN}=\frac{F N}{T P+F N} x 100 \% \\
& \% \mathrm{FP}=\frac{F P}{T P+T N} x 100 \% \\
& \% \mathrm{TN}=\frac{T N}{T P+T N} x 100 \%
\end{aligned}
$$

Sedangkan untuk mencari nilai total kinerja (T) adalah :

$$
\mathrm{T}=\frac{T P+T N}{T P+T N+F P+F N}
$$

\section{HASIL PENELITIAN DAN \\ PEMBAHASAN}

\subsection{Perhitungan Ekstraksi Citra}

Proses perhitungan untuk melakukan ekstraksi ciri dilakukan dengan menghitung fitur yaitu Semi minor axis length, Semi major axis length, Average radius, Perimeter, Eccentricity, Sphericity, Circularity, Compactness, Moment of inertia, Elongation dan Roundness untuk telur. Sedangkan untuk siklus lain akan digunakan ekstraksi fitur tekstur.

\subsubsection{Hasil Perhitungan Ekstraksi Fitur Nyamuk}

Dari proses perhitungan ektraksi fitur pada citra nyamuk, didapat hasil perhitungan pada tabel 2. Fitur yang terdapat pada tabel 2 merupakan fitur hasil seleksi atribut (feature selection) yang diproses menggunakan aplikasi weka. Fitur - fitur tersebut merupakan fitur yang memiliki peluang besar dalam membedakan jenis nyamuk pada proses klasifikasi.

Hasil rata - rata pada siklus larva, pupa, kepala jantan dan kepala betina dapat dilihat pada tabel selanjutnya yaitu tabel 3 , tabel 4 , tabel 5 dan tabel 6. Untuk siklus kepala, fitur yang digunakan hanya menggunakan fitur tekstur. Maka dari itu hasil seleksi atribut maksimal adalah contrass, correlation dan kurtosis.

\section{b) Hitungan Ekstraksi Nyamuk Anopheles}

Fitur yang terdapat pada tabel 7 merupakan fitur hasil seleksi atribut (feature selection) yang diproses menggunakan aplikasi weka. Fitur - fitur tersebut merupakan fitur yang memiliki peluang besar dalam membedakan jenis nyamuk pada proses klasifikasi.

Hasil rata - rata pada siklus larva, pupa, kepala jantan dan kepala betina nyamuk Anopheles dapat dilihat pada tabel selanjutnya yaitu tabel 8 dan tabel 9 .

\section{c) Hitungan Ekstraksi Nyamuk Culex}

Fitur yang terdapat pada tabel 10 merupakan fitur hasil seleksi atribut (feature selection) yang diproses menggunakan aplikasi weka. Fitur - fitur tersebut merupakan fitur yang memiliki peluang besar dalam membedakan jenis nyamuk pada proses klasifikasi.

Hasil rata - rata pada siklus larva, pupa, kepala jantan dan kepala betina nyamuk Culex dapat dilihat pada tabel selanjutnya yaitu tabel 11, tabel 12 dan tabel 13 . 
Tabel 10. Hitungan Seleksi Fitur Telur Culex

\begin{tabular}{cc}
\hline Fitur & Rata - Rata Culex \\
\hline Semi minor axis length & 527,8010261 \\
Semi minor axis length & 1811,925486 \\
Average radius & 709,6395 \\
Perimeter & 4458,796534 \\
Eccentricity & 0,956614652 \\
Sphericity & 0,539710166 \\
Circularity & 0,466872024 \\
Compactness & 27,05426 \\
Moment of inertia & 4314024,739 \\
Elongation & 0,291308911 \\
Roundness & $3,08103 \mathrm{E}+12$ \\
\hline
\end{tabular}

Tabel 11. Hitungan Seleksi Fitur Larva Culex

\begin{tabular}{cc}
\hline Fitur & Rata - Rata Culex \\
\hline Semi minor axis length & 1052,378458 \\
Equivalent diameter & 1217,835 \\
Variance radius & 0,154078223 \\
Contrast & 6577603039430,00 \\
\hline
\end{tabular}

Tabel 12. Hitungan Seleksi Fitur Pupa Culex

\begin{tabular}{cc}
\hline Fitur & Rata - Rata Culexs \\
\hline Contrast & 0,051865958 \\
Correlation & 0,942047907 \\
Kurtosis & 0,503479725 \\
\hline
\end{tabular}

Tabel 13. Hasil Seleksi Fitur Kepala Nyamuk Culex

\begin{tabular}{cc}
\hline Fitur & Rata - Rata Culexs \\
\hline Contrast & 0,090648662 \\
Correlation & 0,94840378 \\
Kurtosis & 0,323403981 \\
\hline
\end{tabular}


Tabel 14. Hitungan Seleksi Fitur Telur Mansonia

\begin{tabular}{cc}
\hline Fitur & Rata - Rata Mansonia \\
\hline Semi minor axis length & 373,286741 \\
Semi minor axis length & 1696,888555 \\
Average radius & 1713,849462 \\
Perimeter & 10768,43376 \\
Eccentricity & 0,959420886 \\
Sphericity & 0,502906024 \\
Circularity & 0,09172099 \\
Compactness & 513,3335763 \\
Moment of inertia & 4080976,881 \\
Elongation & 0,262116416 \\
Roundness & $2,36605 \mathrm{E}+12$ \\
\hline
\end{tabular}

Tabel 15. Hitungan Seleksi Fitur Larva Mansonia

\begin{tabular}{cc}
\hline Fitur & Rata - Rata Larva Mansonia \\
\hline Semi minor axis length & 917,9326219 \\
Equivalent diameter & 757,3400315 \\
Variance radius & 0,029045253 \\
Contrast & 1881146726924,21 \\
\hline
\end{tabular}

Tabel 16. Hitungan Seleksi Fitur Pupa Mansonia

\begin{tabular}{cc}
\hline Fitur & Rata - Rata Pupa Mansonia \\
\hline Semi minor axis length & 850,6636 \\
Semi minor axis length & 1568,433 \\
Average radius & 4409,96 \\
Perimeter & 27708,6 \\
Compactness & 873,3036 \\
Moment of inertia & 4268488 \\
Contrast & 0,051956 \\
Correlation & 0,917314 \\
Kurtosis & 0,60765 \\
\hline
\end{tabular}

\section{d) Hitungan Ekstraksi Nyamuk Mansonia}

Fitur yang terdapat pada tabel 14 merupakan ekstraksi fitur telur hasil seleksi atribut (feature selection) yang diproses menggunakan aplikasi weka. Fitur-fitur tersebut merupakan fitur yang memiliki peluang besar dalam membedakan jenis nyamuk pada proses klasifikasi.
Hasil rata - rata pada siklus larva, pupa, kepala jantan dan kepala betina nyamuk Mansonia dapat dilihat pada tabel 15 dan tabel 16.

Hasil ekstraksi tersebut menyesuaikan dengan preparat nyamuk yang tersedia di laboratorium FK UII. Jadi tidak menutup kemungkinan jika ada siklus yang tidak lengkap dalam setiap jenis nyamuk. 
Tabel 17. Tabel Akurasi dengan 12 Fitur Telur

\begin{tabular}{ccc}
\hline $\mathbf{k}$ & Max Accuracy & Jumlah fitur \\
\hline 3 & $91.3043 \%$ & 12 \\
5 & $82.6087 \%$ & 12 \\
7 & $78.2609 \%$ & 12 \\
3 & $91.3043 \%$ & 10 \\
5 & $86.9565 \%$ & 10 \\
7 & $82.6087 \%$ & 10 \\
\hline
\end{tabular}

Tabel 18. Tabel Akurasi dengan 3 Fitur Larva

\begin{tabular}{ccc}
\hline $\mathbf{k}$ & Max Accuracy & Jumlah fitur \\
\hline 1 & $52.9412 \%$ & 3 \\
3 & $52.9412 \%$ & 3 \\
5 & $47.0588 \%$ & 3 \\
7 & $41.1765 \%$ & 3 \\
9 & $35.2941 \%$ & 3 \\
\hline
\end{tabular}

Tabel 19. Tabel Akurasi Siklus Pupa

\begin{tabular}{ccc}
\hline $\mathbf{k}$ & Max Accuracy & Jumlah fitur \\
\hline 1 & $100 \%$ & 2 \\
3 & $50 \%$ & 2 \\
5 & $42.3077 \%$ & 2 \\
\hline
\end{tabular}

Tabel 20. Tabel Akurasi dengan 13 Fitur Nyamuk Dewasa

\begin{tabular}{ccc}
\hline $\mathbf{k}$ & Max Accuracy & Jumlah fitur \\
\hline 1 & $45.4545 \%$ & 13 \\
3 & $31.8182 \%$ & 13 \\
5 & $50 \%$ & 13 \\
7 & $54.5455 \%$ & 13 \\
\hline
\end{tabular}

\subsection{Hasil Klasifikasi}

\subsubsection{Klasifikasi Siklus Telur}

Pada tabel 17 dan 18 terlihat perbedaan dalam tingkat akurasi ketika menggunakan $\mathrm{k}=3, \mathrm{k}=5$, dan $\mathrm{k}=7$. Jumlah fitur yang digunakan tidak mempengaruhi akurasi tertinggi yaitu $91,3043 \%$.

Pada tabel 18 dapat dilihat akurasi data dengan jarak $\mathrm{k}$ yang berbeda-beda. Nilai akurasi tertinggi adalah $\mathrm{k}=1$ dan $\mathrm{k}=3$ yang memiliki tingkat akurasi 52,9412\%.

Pada tabel 19 terlihat perbedaan akurasi pada setiap jarak k yang digunakan. Akurasi tertinggi dengan menggunakan $\mathrm{k}=1$. Fitur yang digunakan pada siklus pupa ini adalah contrass dan correlation.
Pada tabel 20 terlihat perbedaan dalam tingkat akurasi dengan menggunakan jarak $\mathrm{k}$ yang berbeda - beda. Jumlah fitur yang digunakan berjumlah 13 fitur tanpa ada seleksi atribut. Dengan 13 fitur tersebut didapatkan tingkat akurasi tertinggi adalah $54,5455 \%$.

\subsection{Pengujian White Box Testing}

Berdasarkan uji dengan metode whitebox testing, sistem telah bekerja sesuai dengan perancangan yang telah direncanakan. Belum ada error yang ditemui ketika dalam proses ekstraksi ciri dan klasifikasi. Namun dalam sistem belum terdapat pemberitahuan atau peringatan jika gambar yang dimasukan dalam setiap siklus merupakan siklus yang berbeda. 


\section{KESIMPULAN}

Kesimpulan yang dapat ditarik dari penulisan laporan penelitian ini adalah sebagai berikut.

a. Sistem dapat melakukan klasifikasi dengan melihat perbedaan yang terdapat dalam citra nyamuk melalui ekstraksi ciri fitur. Ciri fitur tersebut antara lain Semi minor axis length, Semi major axis length, Average radius, Perimeter, Eccentricity, Sphericity, Circularity, Compactness, Moment of inertia, Elongation dan Roundness. Ada pula fitur tekstur yang digunakan yaitu fitur entropy, skewness, kurtosis, homogeneity, energy dan variance.

b. Citra nyamuk satu dengan yang lain mempunyai perbedaan yang signifikan pada ciri fitur nya setelah dilakukan seleksi atribut (feature selection).

\section{DAFTAR PUSTAKA}

Dhany, S., 2009. PERANCANGAN SISTEM PAKAR UNTUK DIAGNOSA PENYAKIT ANAK.

Fahmi., 2007. Perancangan Algoritma Pengolahan Citra Mata Sebagai Bentuk Antara Sistem Biometrik.

Ikhsanuddin, R. M., 2014. Identifikasi Citra Pada Plat Nomor Kendaraan Mobil Pribadi Menggunakan Metode K-Nearest Neighbor, 17.

Kurniawan, R., Eling, D., Sasmito, K., \& Suryani, F., 2013. Klasifikasi Sel Serviks Menggunakan Analisis Fitur Nuclei pada Citra Pap Smear. Snimed, (November), 4554.

Putra, D., 2004. Binerisasi citra tangan dengan metode otsu. Teknologi Elektro, 3(2), 11-13.

Soalani, D., 2010.

Peranan_Ordo_Diptera_Nyamuk_D an_Lalat_Da. 